\title{
Dual $\mathrm{Ca}^{2+}$ Requirement for Optimal Lipid Peroxidation of Low Density Lipoprotein by Activated Human Monocytes
}

\author{
Qing Li, * A Ann Tallant, * and Martha K. Cathcart * * \\ ${ }^{*}$ Research Institute, Cleveland Clinic Foundation, Cleveland, Ohio 44195; and ${ }^{\ddagger}$ Department of \\ Regulatory Biology, Cleveland State University, Cleveland, Ohio 44115
}

\begin{abstract}
The oxidative modification of LDL seems a key event in atherogenesis and may participate in inflammatory tissue injury. Our previous studies suggested that the process of LDL oxidation by activated human monocytes/macrophages required $\mathrm{O}_{2}^{-}$and activity of intracellular lipoxygenase. Herein, we studied the mechanisms involved in this oxidative modification of LDL. In this study, we used the human monocytoid cell line U937 to examine the role of $\mathrm{Ca}^{2+}$ in $\mathrm{U} 937$ cell-mediated lipid peroxidation of LDL. U937 cells were activated by opsonized zymosan. Removal of $\mathrm{Ca}^{2+}$ from cell culture medium by EGTA inhibited U937 cell-mediated peroxidation of LDL lipids. Therefore, $\mathrm{Ca}^{2+}$ influx and mobilization were examined for their influence on U937 cell-mediated LDL lipid peroxidation. $\mathrm{Ca}^{2+}$ channel blockers nifedipine and verapamil blocked both $\mathrm{Ca}^{2+}$ influx and LDL lipid peroxidation by activated U937 cells. The inhibitory effects of nifedipine and verapamil were dose dependent. TMB8 and ryanodine, agents known to prevent $\mathrm{Ca}^{2+}$ release from intracellular stores, also caused a dose-dependent inhibition of LDL lipid peroxidation by activated U937 cells while exhibiting no effect on $\mathrm{Ca}^{2+}$ influx. Thus, both $\mathrm{Ca}^{2+}$ influx through functional calcium channels and $\mathrm{Ca}^{2+}$ mobilization from intracellular stores participate in the oxidative modification of $\mathrm{LDL}$ by activated $\mathrm{U} 937$ cells. ${ }^{45} \mathrm{Ca}^{2+}$ uptake experiments revealed profound $\mathrm{Ca}^{2+}$ influx during the early stages of $\mathrm{U} 937$ cell activation, however, the $\mathrm{Ca}^{2+}$ ionophore 4-bromo $\mathrm{A} 23187$ was unable to induce activation of $\mathrm{U} 937$ cells and peroxidation of $\mathrm{LDL}$ lipids. Release of intracellular $\mathrm{Ca}^{2+}$ by thapsigargin only caused a suboptimal peroxidation of LDL lipids. Our results indicate that although increases in intracellular $\mathrm{Ca}^{2+}$ levels provided by both influx and intracellular $\mathrm{Ca}^{2+}$ mobilization are required, other intracellular signals may be involved for optimal peroxidation of LDL lipids by activated human monocytes. (J. Clin. Invest. 1993.91:1499-1506.) Key words: human macrophages • calcium influx • calcium mobilization • signal transduction $\cdot$ low density lipoprotein peroxidation
\end{abstract}

This work was presented in part at the annual meeting for the Society for Leukocyte Biology, Aspen, CO, Sept. 28- Oct. 1, 1991, and published in abstract form ( $\mathrm{Li}$, Q., and M. K. Cathcart. 1991. The calcium requirement of LDL oxidation by $\mathrm{U} 937$ cells. J. Leukocyte Biol. 2[Suppl.]:61.)

Address correspondence to Martha K. Cathcart, Ph.D., Cell Biology Cleveland Clinic Foundation, 9500 Euclid Ave., Cleveland, OH 44195.

Received for publication 22 May 1992 and in revised form 24 September 1992

J. Clin. Invest.

(c) The American Society for Clinical Investigation, Inc.

$0021-9738 / 93 / 04 / 1499 / 08 \$ 2.00$

Volume 91, April 1993, 1499-1506

\section{Introduction}

Activated human monocytes/macrophages can oxidize normal human LDL and transform it to a cytotoxin (1). The process of LDL lipid peroxidation by activated human monocytes has been shown to require superoxide anion $\left(\mathrm{O}_{2}^{-}\right)$released from activated monocytes/macrophages, since scavenging of $\mathrm{O}_{2}^{-}$by superoxide dismutase prevents peroxidation of LDL lipids (2). Metal ion chelators and general antioxidants can also inhibit monocyte-mediated peroxidation of LDL lipids $(1,2)$. Our previous studies suggested that there was an initiation of oxidation by $\mathrm{O}_{2}^{-}$and propagation of oxidation mediated by other free radicals, possibly lipid radicals (2). It was also found that intracellular lipoxygenase was essential for oxidation of LDL lipids (3). Cellular lipoxygenases catalyze the oxidation of polyunsaturated fatty acids to fatty acid hydroperoxides. Fatty acid hydroperoxides may propagate oxidation by forming reactive lipid peroxyl radicals.

Oxidized LDL has been shown to be toxic to proliferating target cells in vitro, such as fibroblasts and endothelial cells ( 1 , $4,5)$. If activated monocytes/macrophages were able to oxidize LDL in vivo, the resultant toxic lipoproteins could mediate tissue injury in a variety of inflammatory responses. This may likely occur in the developing atherosclerotic lesion where lipid-laden foam cells of monocyte origin are surrounded by LDL accumulating in high concentration in the vascular interstitial space $(5,6)$. Thus, it appears that phagocyte-derived free radicals, both superoxide anion and lipid peroxyl radicals, oxidize LDL and that the products of lipid peroxidation carried by oxidized LDL can effect more extensive or more distant tissue injury than that directly mediated by monocyte-derived free radicals.

Although both the release of reactive oxygen species by activated human monocytes/macrophages and the requirement for cellular lipoxygenases have been correlated with oxidation of LDL lipids, the precise mechanisms involved in the oxidation are not entirely understood. In particular, little is known regarding the intracellular signaling required for activated monocytes to mediate oxidation of LDL. Studies on the required intracellular signaling can help elucidate the specific mechanisms of activated monocyte-mediated oxidation of LDL and conversion of LDL to cytotoxin as well as suggest optimal means for intervening and preventing this process.

For the majority of our studies opsonized zymosan (ZOP) ${ }^{1}$ has been used as the activation stimulus for human monocytes. $Z O P$ resembles a type of stimulus that might be encountered in vivo. Since ZOP can activate the monocyte through Fc recep-

1. Abbreviations used in this paper: $\mathrm{IC}_{50}$, inhibitory concentration; LPO, lipid peroxide; MDA, malondialdehyde; PLC, phospholipase C; TBA, thiobarbituric acid; TMB, 8-( $N, N$-diethylamino)octyl 3,4,5-trimethoxybenzoate hydrochloride; ZOP, opsonized zymosan. 
tors, complement receptors, and as a stimulator of phagocytosis (7), it is likely that several secondary messenger pathways of signal transduction are put into motion. Our hypothesis regarding activation signals and their transduction to intracellular signaling systems is that upon activation of monocytes $/ \mathrm{mac}$ rophages by ZOP, several intracellular signal transduction systems are involved and that some of these may be required for cell-mediated LDL oxidation whereas others may not. Several secondary messenger-generating pathways, such as the activation of lipoxygenases, phospholipases, or protein kinases form networks of coregulation. In a number of these signal transduction pathways, $\mathrm{Ca}^{2+}$ is a critical mediator. Thus, in this study we evaluated the importance of $\mathrm{Ca}^{2+}$ influx from the extracellular environment and $\mathrm{Ca}^{2+}$ mobilization from intracellular stores in the peroxidation of LDL lipids by activated macrophages.

It has been reported that $\mathrm{Ca}^{2+}$ channel blockers may prevent atherogenesis (8); however, the precise mechanisms remain to be elucidated. In this paper, classic slow $\mathrm{Ca}^{2+}$ channel blockers known to block $\mathrm{Ca}^{2+}$ entry through selective $\mathrm{Ca}^{2+}$ channels in the plasma membrane were used to block the entry of extracellular $\mathrm{Ca}^{2+}$ from cell culture medium. Agents known to prevent release of intracellular $\mathrm{Ca}^{2+}$ from internal membrane stores were also tested. Data presented here indicate that both extracellular and intracellular $\mathrm{Ca}^{2+}$ contribute to the process of peroxidation of LDL lipids induced by activated human macrophages. Prevention of $\mathrm{Ca}^{2+}$ entry or $\mathrm{Ca}^{2+}$ mobilization substantially interferes with the conversion of normal LDL to an oxidized and toxic entity. Our data also suggest that neither of these $\mathrm{Ca}^{2+}$ resources alone is sufficient for fully triggering monocyte-mediated LDL lipid peroxidation.

\section{Methods}

\section{Cell culture}

U937 cells obtained from the American Type Culture Collection (Rockville, MD) were cultured in 150- $\mathrm{cm}^{2}$ flasks (Corning Glass Inc., Corning, NY) in RPMI 1640 (Whittaker Bioproducts, Walkersville, MD) supplemented with $10 \%$ bovine calf serum (Hyclone Laboratories Inc., Logan, UT), $100 \mathrm{U} / \mathrm{ml}$ penicillin, and $100 \mu \mathrm{g} / \mathrm{ml}$ streptomycin (Gibco Laboratories, Grand Island, NY) at $37^{\circ} \mathrm{C}$ in a humidified atmosphere of $90 \%$ air $/ 10 \% \mathrm{CO}_{2}$. U937 cells were maintained in log phase and were not allowed to exceed $1 \times 10^{6} / \mathrm{ml}$. For experiments U937 cells were washed twice with RPMI 1640 without serum and 5 $\times 10^{5}$ cells $/ \mathrm{ml}$ were plated into 12 -well tissue culture plates (Costar Corp., Cambridge, MA). U937 cells were cocultured with $0.5 \mathrm{mg} \mathrm{LDL}$ cholesterol $/ \mathrm{ml}$. Various reagents were included during the 24-h incubation of U937 cells with LDL as noted to test for their effects on U937 cell-mediated lipid peroxidation of LDL. The total volume per well was $1.0 \mathrm{ml}$.

\section{Lipoprotein preparation}

LDL was prepared according to previously described methods that minimize oxidation and exposure to endotoxin (9). Each batch of LDL was assayed for endotoxin contamination by the Limulus amebocyte lysate assay. Final endotoxin contamination was $<0.015 \mathrm{U} / \mathrm{ml}$. LDL was stored in $0.5 \mathrm{mM}$ EDTA and adjusted to $10 \mathrm{mg}$ cholesterol/ $\mathrm{ml}$. Immediately before use, LDL was dialyzed at $4^{\circ} \mathrm{C}$ against phosphate-buffered saline without calcium or magnesium (Gibco Laboratories). LDL was used at a final concentration of $0.5 \mathrm{mg}$ cholesterol $/ \mathrm{ml}$.

\section{Measurement of lipid peroxidation}

The peroxidation of LDL lipids was measured by both the thiobarbituric acid (TBA) assay and lipid peroxide (LPO) assay.
$T B A$ assay. The presence of lipid oxidation products on LDL was determined by a modification of the assay described by Schuh et al. (10), which detects malondialdehyde (MDA) and MDA-like compounds reacting with TBA. Compounds that react with TBA are referred to as TBA-reactive substances (TBARS). Briefly, $0.75 \mathrm{ml} \mathrm{25 \%}$ trichloroacetic acid was added to $0.3-\mathrm{ml}$ samples, followed by $0.75 \mathrm{ml}$ of $1 \%$ TBA. The samples were then vortexed and incubated for $45 \mathrm{~min}$ at $95^{\circ} \mathrm{C}$; after which they were centrifuged $(1,000 \mathrm{~g})$ for $15 \mathrm{~min}$. Supernatant TBARS were detected by fluorescence at $515 \mathrm{~nm}$ excitation and $553 \mathrm{~nm}$ emission. Malondialdehyde bis (dimethyl acetal), i.e., 1,1,3,3, tetramethoxypropane (Aldrich Chemical Co., Milwaukee, WI) was used as the standard at concentrations of $0-10 \mathrm{nmol} \mathrm{MDA} / \mathrm{ml}$. Samples were assayed in duplicate. Data represent the mean \pm SEM of experimental results obtained in three similar experiments and are expressed in terms of MDA equivalents ( $\mathrm{nmol} \mathrm{MDA} / \mathrm{ml}$ of sample).

LPO assay. To detect lipid peroxides on LDL we performed the LPO assay of El-Saadani et al. (11). The principle of this assay is based on the oxidative capacity of lipid peroxides to convert iodide to iodine, which can be measured spectrophotometrically at $365 \mathrm{~nm}$. A stoichiometric relationship is observed between the amount of organic peroxides assayed and the concentration of iodine produced (11). Thus, the amount of lipid peroxides can be calculated using an extinction coefficient. For this assay, $100 \mu \mathrm{l}$ of sample were added to $1 \mathrm{ml}$ of working reagent ( $200 \mathrm{mM}$ monobasic potassium phosphate, $\mathrm{pH} 6.2,120 \mathrm{mM}$ potassium iodide, $0.15 \mathrm{mM}$ sodium azide, $2.0 \mathrm{~g} /$ liter Triton X-100, 0.1 $\mathrm{g} /$ liter benzalkonium chloride, $0.01 \mathrm{mM}$ ammonium molybdate, 0.02 $\mathrm{mM}$ butylated hydroxy toluene, and $0.024 \mathrm{mM}$ EGTA) and then incubated in the dark at room temperature for $30 \mathrm{~min}$. After incubation, the samples were read using a spectrophotometer (model DU-64; Beckman Instruments, Inc., Fullerton, CA) at wavelength $365 \mathrm{~nm}$. The quantity of lipid peroxides in samples of oxidized LDL was calculated according to the equation: $\mathrm{nmol}$ lipid peroxide $/ \mathrm{ml}=447.15 \times \mathrm{OD}_{365}$.

\section{${ }^{45} \mathrm{Ca}^{2+}$ uptake assay}

U937 cells at $2 \times 10^{6}$ cells $/ \mathrm{ml}$ in HBSS (Gibco Laboratories) were preincubated at $37^{\circ} \mathrm{C}$ with test agents for $30 \mathrm{~min}$. At zero time, LDL and $\mathrm{ZOP}$ were added together with $2 \mu \mathrm{Ci}^{45} \mathrm{Ca}^{2+} / \mathrm{ml}$. At given time intervals, $100 \mu \mathrm{l}$ of cell suspension was loaded onto $500 \mu \mathrm{l}$ Ficoll-Paque (Pharmacia Inc., Piscataway, NJ) and centrifuged for $2 \mathrm{~min}$ in an Eppendorf centrifuge 5413 . The cells were rapidly filtered under vacuum on GF/C glass-fiber filters (Whatman International Ltd., Maidstone, England) that were previously rinsed with $2 \mathrm{ml}$ HBSS. The filters were further rinsed with $3 \mathrm{ml} \mathrm{HBSS}$, air dried, and placed in $10 \mathrm{ml}$ of scintillation liquid (ICN Biomedicals, Inc., Irvine, CA). Radioactivity was determined with a $\beta$-scintillation counter. All experiments were performed in triplicate.

\section{Detection of toxicity of test agents}

The toxicity of test agents to U937 cells was determined by both the $\left[{ }^{14} \mathrm{C}\right]$ adenine and the $\left[{ }^{51} \mathrm{Cr}\right]$ sodium chromate release assays. These assays gave very similar results when U937 cells were injured with increasing doses of hydrogen peroxide in support of previously published comparisons of these sensitive assays for cell injury/toxicity (12).

$\left[{ }^{14} \mathrm{C}\right]$ adenine release assay (13). Briefly, $1 \times 10^{7} \mathrm{U} 937$ cells in 20 ml RPMI 1640 were labeled overnight by incubating with $10 \mu \mathrm{Ci}\left[{ }^{14} \mathrm{C}\right]-$ adenine (ICN Radiochemicals, Irvine, CA). For experiments, U937 cells were washed twice with RPMI 1640 , and $5 \times 10^{5}$ cells $/ \mathrm{ml}$, ZOP, and LDL were plated into 12-well tissue culture plates in the presence or absence of test agents. After a 24-h incubation, the amount of $\left[{ }^{14} \mathrm{C}\right]-$ adenine release by U937 cells was detected by counting $100 \mu \mathrm{l}$ of the supernatant fluid using a $\beta$-counter (model LS-3801; Beckman Instruments, Inc.). $\left[{ }^{14} \mathrm{C}\right.$ ]adenine release from ZOP-activated U937 cells in the absence of test agents was defined as background and $0 \%$ release and interpreted as a lack of toxicity. $\left[{ }^{14} \mathrm{C}\right]$ adenine release by $0.2 \%$ SDS was defined as $100 \%$ release and interpreted as maximum toxicity. The data are expressed as: \% release $=[($ sample release - background $) /$ (maximum release - background) $] \times 100 \%$. 
$\left[{ }^{51} \mathrm{Cr}\right]$ Sodium chromate release assay (14). $1 \times 10^{7} \mathrm{U} 937$ cells in $20 \mathrm{ml}$ RPMI 1640 were labeled overnight by incubating with $100 \mu \mathrm{Ci}$ of sodium chromate-51 (Du Point/New England Nuclear, Boston, MA). After labeling, the cells were washed twice with RPMI 1640, and 5 $\times 10^{5}$ cells $/ \mathrm{ml}, \mathrm{ZOP}$, and LDL were plated into 12-well tissue culture plates in the presence or absence of test agents. After $24 \mathrm{~h}, 100 \mu \mathrm{l}$ of the supernatants containing released isotope were removed and placed in glass tubes to be counted on a gamma counter. Controls consisted of U937 cells incubated with ZOP ( $0 \%$ release) or $0.2 \%$ SDS ( $100 \%$ release). The data are calculated according to above equation.

\section{Intracellular $\mathrm{Ca}^{2+}$ measurement}

Intracellular $\mathrm{Ca}^{2+}$ was measured using the fluorescent indicator Fura 2 (15). In U937 cells, at $1 \times 10^{7} / \mathrm{ml}$ of Krebs-Ringer solution with the following composition $(\mathrm{mM}):\left(125 \mathrm{NaCl}, 5 \mathrm{KCl}, 1.2 \mathrm{MgSO}_{4}, 6\right.$ glucose, $1 \mathrm{CaCl}_{2}$, and $25 \mathrm{Hepes}, \mathrm{pH} 7.5$ ) containing $0.2 \% \mathrm{BSA}$, were incubated for $20 \mathrm{~min}$ at $37^{\circ} \mathrm{C}$ in $4 \mu \mathrm{M}$ Fura 2-AM (Molecular Probes, Inc., Eugene, OR). The cells were subsequently diluted fourfold and incubated an additional $20 \mathrm{~min}$ to completely hydrolyze the entrapped ester. The cells were pelleted and resuspended at $1.33 \times 10^{6} / \mathrm{ml} \mathrm{Krebs-}$ Ringer solution containing BSA for measurements. Fura 2 measurements were conducted in an air-driven dual-wavelength spectrofluorometer using excitation wavelengths of 340 and $380 \mathrm{~nm}$ and emission at $500 \mathrm{~nm}$. Maximal fluorescence of the $\mathrm{Ca}^{2+}$-saturated dye was measured in the presence of $0.1 \%$ Triton X-100 and minimal fluorescence was measured in the presence of $5 \mathrm{mM}$ EGTA and $32 \mathrm{mM}$ Tris, $\mathrm{pH} 8.3$. Autofluorescence was corrected by measurement in the presence of excess $\mathrm{MnCl}_{2}$. The level of cytosolic $\mathrm{Ca}^{2+}$ was calculated according to the procedure of Grynkiewicz et al. (15).

\section{Chemicals}

8-( $N, N$-diethylamino)octyl 3,4,5-trimethoxybenzoate hydrochloride (TMB-8), nifedipine, and verapamil were purchased from Biomol Research Laboratories, Inc. (Plymouth Meeting, PA). Ethylene glycolbis $(\beta$-aminoethyl ether) tetracetic acid (EGTA), lanthanum chloride, and 4-bromo A23187 were purchased from Sigma Chemical Co. (St. Louis, MO). Ryanodine was purchased from Progressive Agri Systems, Inc. (Wind Gap, PA). Thapsigargin was purchased from Cal Biochem (San Diego, CA). Zymosan, purchased from ICN Nutritional Biochemicals (Cleveland, $\mathrm{OH}$ ), was opsonized (16) and used at a concentration of $2 \mathrm{mg} / \mathrm{ml}$ to activate U937 cells. TMB-8, nifedipine, verapamil, ryanodine, 4-bromo $\mathrm{A} 23187$, and thapsigargin were solubilized in DMSO as 100 -fold stock solutions. EGTA and lanthanum chloride were solubilized in $\mathrm{H}_{2} \mathrm{O}$ as 100 -fold stock solutions. Opsonized zymosan was suspended in RPMI 1640 as 20 -fold stock solutions. For experiments these reagents were diluted to designated concentrations in RPMI 1640 as indicated.

\section{Results}

The TBA assay is a widely used method to detect MDA and MDA-like compounds derived from lipid oxidation products (10); and the LPO assay is used to detect the presence of lipid peroxides (11). In our studies both of these methods were used to detect the lipid oxidation products on LDL mediated by activated human monocytes. U937 cells, ZOP, and LDL were incubated together for $24 \mathrm{~h}$. Results of three experiments are summarized in Fig. 1. LDL was significantly oxidized by ZOPactivated U937 cells as detected by both the TBA assay (Fig. 1 $A$ ) and the LPO assay (Fig. $1 B$ ). Little if any lipid peroxidation was observed in cocultures of LDL and unactivated U937 cells. Removal of $\mathrm{Ca}^{2+}$ from the cell culture medium (there is 0.4 $\mathrm{mM} \mathrm{Ca}{ }^{2+}$ in RPMI 1640) by adding the $\mathrm{Ca}^{2+}$-chelating agent EGTA resulted in inhibition of LDL lipid peroxidation by activated U937 cells. In the presence of EGTA the peroxidation of LDL lipids by ZOP-activated U937 cells was decreased in a

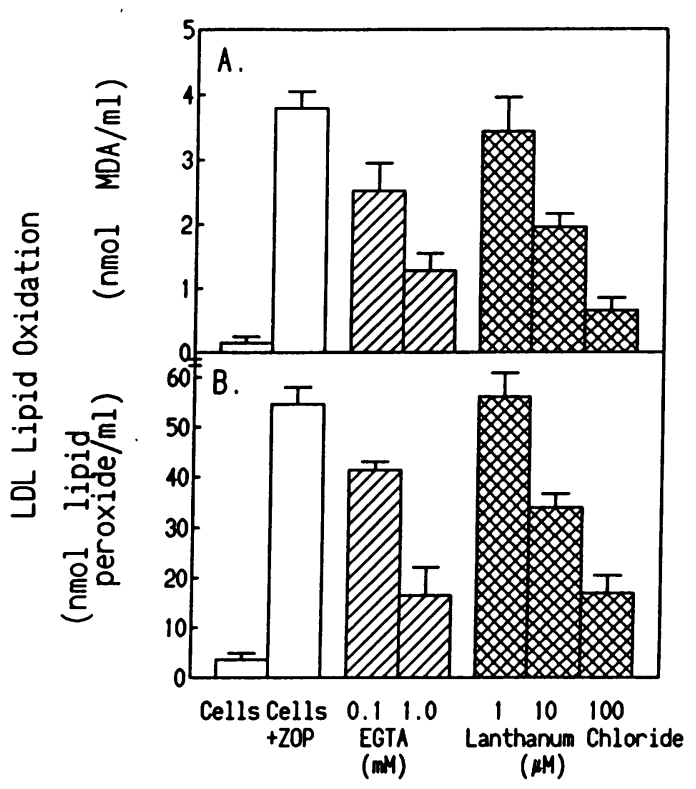

Figure 1. LDL lipid peroxidation by activated U937 cell is inhibited by EGTA and lanthanum chloride. A total $5 \times 10^{5}$ cells were incubated with LDL and ZOP $(2 \mathrm{mg} / \mathrm{ml})$ in the presence (hatched bars) or absence (open bar) of EGTA or lanthanum chloride at $37^{\circ} \mathrm{C}$ for $24 \mathrm{~h}$ in a humidified incubator with $10 \% \mathrm{CO}_{2}$. Different concentrations of test reagents were added to ZOP-activated U937 cells as indicated: EGTA $0.1 \mathrm{mM}$ and $1 \mathrm{mM}$ or lanthanum chloride 1,10 , and $100 \mu \mathrm{M}$. After incubation, LDL lipid peroxidation was assessed by both the TBA assay and the LPO assay as described in Methods. The data are depicted as the mean \pm SEM of data obtained in three similar experiments. $(A)$ Oxidation of LDL lipids was measured by the TBA assay and expressed as nmol MDA $/ \mathrm{ml}$. ( $B)$ The degree of lipid peroxidation was measured by the LPO assay and expressed as nmol lipid peroxide $/ \mathrm{ml}$.

dose-dependent fashion. Lanthanum chloride $(1,10$, and 100 $\mu \mathrm{M})$ also showed dose-dependent inhibition of LDL lipid peroxidation by ZOP-activated U937 cells, thus indicating an important role for $\mathrm{Ca}^{2+}$.

Since there are two sources of $\mathrm{Ca}^{2+}$ that are available to the cell, namely influx from the extracellular medium and release from intracellular stores, we first examined the role of $\mathrm{Ca}^{2+}$ influx in the monocyte-mediated peroxidation of LDL lipids. We evaluated the effect of two structurally different $\mathrm{Ca}^{2+}$ channel blockers at various concentrations. U937 cells, ZOP, LDL, and various $\mathrm{Ca}^{2+}$ channel blockers were incubated together. In the absence of $\mathrm{Ca}^{2+}$ channel blockers, the LDL lipid peroxidation mediated by activated U937 cells was $3.78 \mathrm{nmol} \mathrm{MDA} / \mathrm{ml}$ and $55.45 \mathrm{nmol}$ lipid peroxide $/ \mathrm{ml}$, respectively. The results of three experiments are shown in Fig. 2. Both verapamil (Fig. 2 $A$ ) and nifedipine (Fig. $2 B$ ) significantly inhibited peroxidation of lipids on LDL in a concentration-dependent manner. Our results show that both $\mathrm{Ca}^{2+}$ channel blockers inhibited LDL lipid peroxidation by activated U937 cells. The influx of extracellular $\mathrm{Ca}^{2+}$ was thus required for oxidation of LDL lipids by ZOP-activated U937 cells.

The participation of $\mathrm{Ca}^{2+}$ released from intracellular stores was also examined. Data shown in Fig. 3 indicate that prevention of release of $\mathrm{Ca}^{2+}$ from intracellular stores by adding either ryanodine (Fig. $3 A$ ) or TMB-8 (Fig. $3 B$ ) resulted in a dose-dependent inhibition of LDL lipid peroxidation by activated U937 cells as detected by both the TBA assay and the LPO 


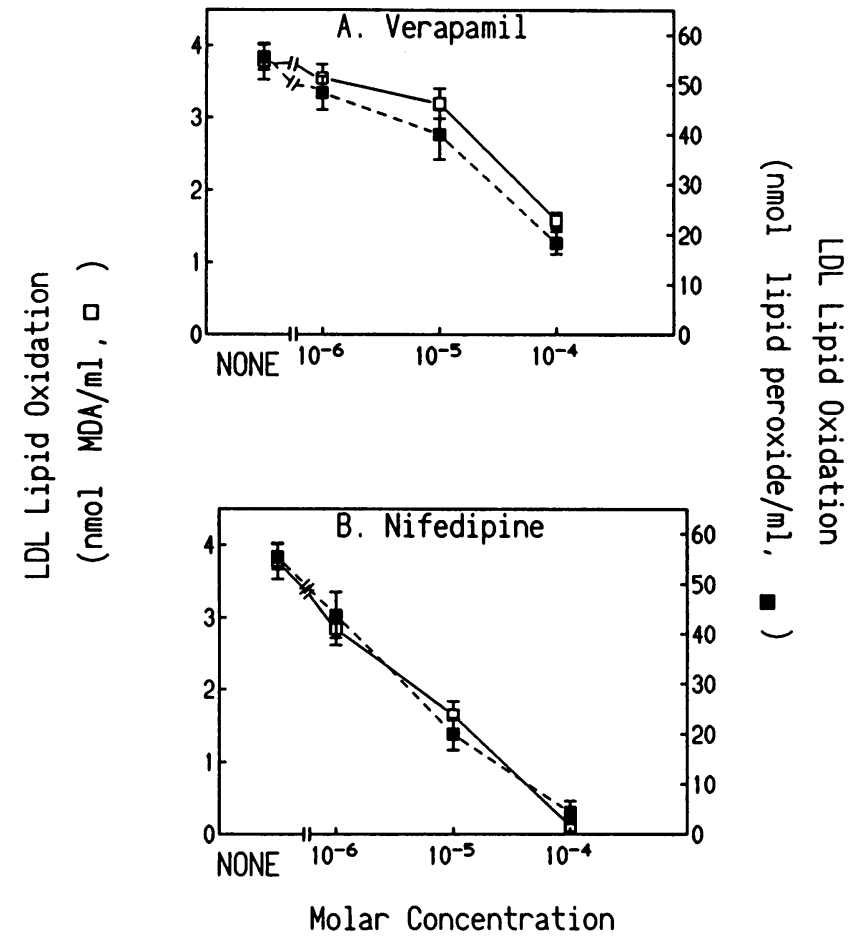

Figure 2. $\mathrm{Ca}^{2+}$ channel blockers, nifedipine and verapamil, inhibit LDL lipid peroxidation by activated U937 cells. U937 cells $\left(5 \times 10^{5}\right.$ cells $/ \mathrm{ml})$ were incubated with LDL and ZOP $(2 \mathrm{mg} / \mathrm{ml})$ in the presence of $\mathrm{Ca}^{2+}$ channel blockers. The incubation was at $37^{\circ} \mathrm{C}$ for 24 $\mathrm{h}$ in a humidified incubator with $10 \% \mathrm{CO}_{2}$. After incubation, peroxidation of LDL lipids was determined by both the TBA assay (left ordinate, open squares and solid lines) and the LPO assay (right ordinate, closed squares and dashed lines) as described in Methods. The data are depicted as the mean \pm SEM in $\mathrm{nmol} \mathrm{MDA} / \mathrm{ml}$ or $\mathrm{nmol}$ lipid peroxide/ $\mathrm{ml}$ of three similar experiments. $(A)$ Activated U937 cells were incubated with LDL and 1,10 , or $100 \mu \mathrm{M}$ verapamil or without verapamil. $(B)$ Activated U937 cells were incubated with LDL and 1,10 , or $100 \mu \mathrm{M}$ nifedipine or without nifedipine.

assay. These results suggest that either blockade of $\mathrm{Ca}^{2+}$ entry or prevention of $\mathrm{Ca}^{2+}$ mobilization from internal stores inhibited monocyte-mediated peroxidation of LDL lipids by activated U937 cells.

By using ${ }^{45} \mathrm{Ca}^{2+}$ labeling, we found that peak $\mathrm{Ca}^{2+}$ influx in ZOP-activated U937 cells occurred during the first hour of activation (data not shown). In these experiments we also examined the effects of nifedipine, verapamil, lanthanum chloride, TMB-8, and ryanodine on ${ }^{45} \mathrm{Ca}^{2+}$ uptake after activation of U937 cells. To obtain sufficient uptake of ${ }^{45} \mathrm{Ca}^{2+}$ in these experiments, the concentration of U937 cells was fourfold higher than in the LDL lipid peroxidation experiments; accordingly we increased the concentrations of these hydrophobic test agents by fourfold as well to keep the same ratio of test agents to cells. U937 cells $\left(2 \times 10^{6}\right.$ cells $\left./ \mathrm{ml}\right)$ were preincubated with test agents for $30 \mathrm{~min}$. At zero time, LDL, ZOP, and ${ }^{45} \mathrm{Ca}^{2+}$ were added together. After $1 \mathrm{~h}$ of incubation, $100 \mu \mathrm{l}$ of the cell suspension was treated to remove the ZOP and uptake of ${ }^{45} \mathrm{Ca}^{2+}$ was determined. The results of a representative experiment are demonstrated in Fig. 4. There was an eightfold increase in ${ }^{45} \mathrm{Ca}^{2+}$ uptake in ZOP-activated U937 cells. Significant blockade of ${ }^{45} \mathrm{Ca}^{2+}$ influx was caused by 40 and $400 \mu \mathrm{M}$ nifedipine, 40 and $400 \mu \mathrm{M}$ lanthanum chloride, or by $400 \mu \mathrm{M}$ verapamil

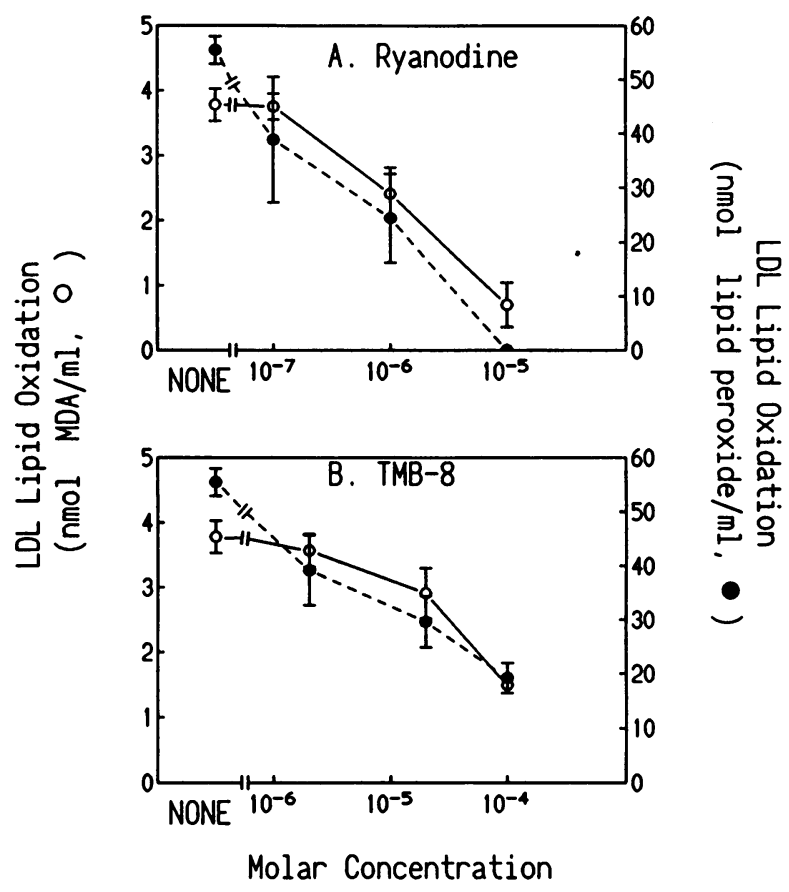

Figure 3. Agents that prevent release of $\mathrm{Ca}^{2+}$ from intracellular stores inhibit LDL lipid peroxidation by activated U937 cells. U937 cells $\left(5 \times 10^{5}\right.$ cells $\left./ \mathrm{ml}\right)$ were incubated with LDL and TMB-8 or ryanodine for $24 \mathrm{~h}$. The incubation conditions were the same as indicated in Fig. 2. After $24 \mathrm{~h}$ incubation LDL lipid peroxidation was determined by both the TBA assay (left ordinate, open circles and solid lines) and the LPO assay (right ordinate, closed circles and dashed lines) as described in Methods. The data are depicted as the mean \pm SEM of three similar experiments. $(A)$ Activated U937 cells were incubated with $\mathrm{LDL}$ and $0.1,1$, or $10 \mu \mathrm{M}$ ryanodine or without ryanodine. $(B)$ Activated $U 937$ cells were incubated with LDL and 2,20 , or $100 \mu \mathrm{M}$ TMB-8 or without TMB-8.

$(P<0.05)$. As expected, neither TMB-8 nor ryanodine blocked ${ }^{45} \mathrm{Ca}^{2+}$ influx by ZOP-activated U937 cells.

To determine whether $\mathrm{Ca}^{2+}$ release from intracellular stores and influx of $\mathrm{Ca}^{2+}$ from extracellular sources regulated different aspects of monocyte-mediated LDL lipid peroxidation, we investigated whether the inhibitory effects of these agents were additive. We found that the inhibition of monocyte-mediated LDL lipid peroxidation was significantly greater with ryanodine and nifedipine or verapamil together than that caused by any of these agents alone. The results of experiments are displayed in Fig. 5. Ryanodine $(1 \mu \mathrm{M})$ significantly increased the inhibitory effects of verapamil $(1,10$, or $100 \mu \mathrm{M})$ and nifedipine ( 1 or $10 \mu \mathrm{M}$ ) on LDL lipid peroxidation by activated U937 cells $(P<0.05)$. A similar statistically significant additive effect was observed with TMB-8 ( 20 or $100 \mu \mathrm{M}$ ) plus nifedipine ( 1 or $10 \mu \mathrm{M}$ ) (data not shown).

We also calculated the $\mathrm{IC}_{50}$ for nifedipine, TMB-8, and ryanodine. These were, respectively, 9.71, 99.77, and $1.63 \mu \mathrm{M}$ for the production of TBA-reactive material and 11.3, 110.2, and $1.2 \mu \mathrm{M}$ for the LPO assay. Since the relationship between the concentration of verapamil and the inhibitory effect were not linear, we did not calculate the $\mathrm{IC}_{50}$ of verapamil. These concentrations are very similar for the two measures of lipid peroxidation and are consistent with those shown to inhibit $\mathrm{Ca}^{2+}$ channels or $\mathrm{Ca}^{2+}$ release in other cell systems (17-19). 


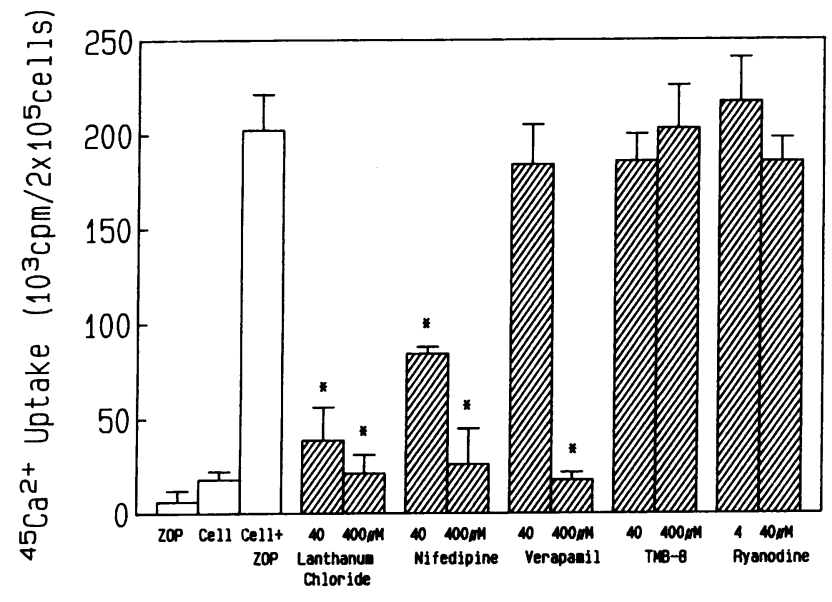

Figure $4 .{ }^{45} \mathrm{Ca}^{2+}$ uptake by ZOP-activated U937 cells. U937 cells ( 2 $\times 10^{6}$ cells $/ \mathrm{ml}$ ) in HBSS were preincubated with test agents at $37^{\circ} \mathrm{C}$ for $30 \mathrm{~min}$. At zero time, LDL and ZOP were added together with 2 $\mu \mathrm{Ci}^{45} \mathrm{Ca}^{2+} / \mathrm{ml}$. At given time intervals, $2 \times 10^{5}$ cells were separated, filtered and counted with a $\beta$-scintillation counter as described in Methods. All experiments were performed in triplicate. The results are presented as mean \pm SD of data obtained in one of two similar experiments. Open bars show experimental results without test agents. Hatched bars show experimental results with different test agents as indicated. 40 and $400 \mu \mathrm{M}$ nifedipine, 40 and $400 \mu \mathrm{M}$ lanthanum chloride significantly inhibits ${ }^{45} \mathrm{Ca}^{2+}$ influx $\left({ }^{*} P<0.05\right) .400 \mu \mathrm{M}$ verapamil also significantly inhibits ${ }^{45} \mathrm{Ca}^{2+}$ influx $\left({ }^{*} P<0.05\right)$. The significance of inhibition was determined by Student's $t$ test.

To examine the $\mathrm{Ca}^{2+}$ involvement in activating $\mathrm{U} 937$ cells to oxidize LDL, a $\mathrm{Ca}^{2+}$ ionophore was tested for its ability to induce LDL lipid peroxidation by U937 cells. In these experiments, U937 cells $\left(5 \times 10^{5}\right.$ cells $\left./ \mathrm{ml}\right), \mathrm{LDL}$, and 4-bromo A23187 $(0.1$ and $1 \mu \mathrm{M})$ were incubated together. After $24 \mathrm{~h}$ of

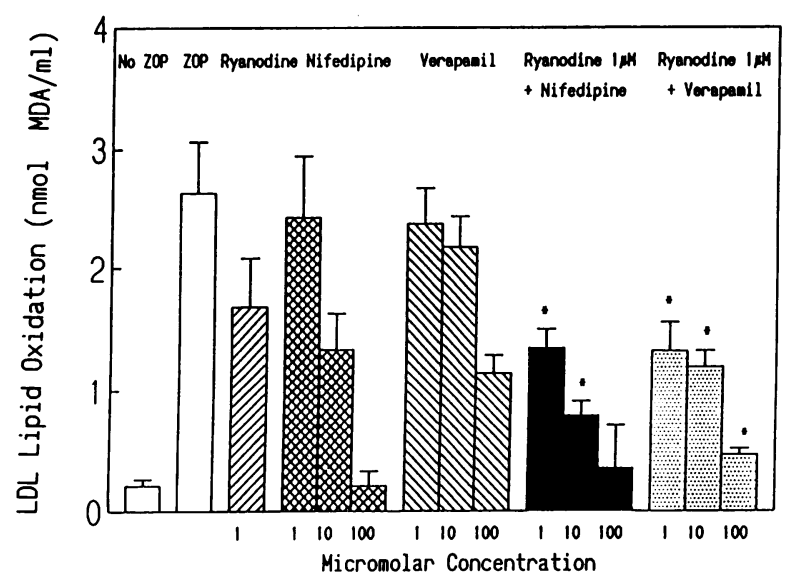

Figure 5. Ryanodine plus verapamil or nifedipine causes greater inhibition of LDL lipid peroxidation by activated U937 cells than any of these drugs alone. U937 cells $\left(5 \times 10^{5}\right.$ cells $\left./ \mathrm{ml}\right)$ were incubated in the presence (filled bars) or absence (open bars) of test agents as indicated. The incubation conditions were the same as indicated in Fig. 2. After the 24-h incubation, LDL lipid peroxidation was determined as described in Methods. The data are depicted as the mean \pm SEM of three similar experiments. The significance of the inhibition by both drugs together as compared with either drug separately was determined by Student's $t$ test $\left({ }^{*} P<0.05\right)$. incubation, LDL lipid peroxidation was measured. Data of representative experiments are shown in Fig. 6. 4-bromo A23187 failed to induce U937 cell-mediated LDL lipid peroxidation. We also tested whether triggering $\mathrm{Ca}^{2+}$ release from intracellular stores could induce LDL lipid peroxidation by U937 cells. Thapsigargin, which is known to induce the release of intracellular $\mathrm{Ca}^{2+}$ from internal membrane stores (20), was used. Data are shown in Fig. 6. $1 \mu \mathrm{M}$ thapsigargin did not induce peroxidation of LDL lipids by U937 cells whereas $10 \mu \mathrm{M}$ thapsigargin (the maximal nontoxic dosage as determined by $\left[{ }^{14} \mathrm{C}\right]$ adenine release, data not shown) induced LDL lipid peroxidation to $35 \%$ of that mediated by ZOP-activated U937 cells. We also examined thapsigargin-induced intracellular $\mathrm{Ca}^{2+}$ release by using Fura 2-loaded cells. As expected, thapsigargin caused release of intracellular $\mathrm{Ca}^{2+}$ from a basal level of $70 \mathrm{nM}$ to 1.3 $\mu \mathrm{M}$ (Fig. 6, inset) without causing a change in influx of extracellular $\mathrm{Ca}^{2+}$ as indicated by ${ }^{45} \mathrm{Ca}^{2+}$ uptake (data not shown).

To evaluate the cytotoxicity of the agents used in these studies, we tested the toxicity of $\mathrm{Ca}^{2+}$ channel blockers and inhibitors of intracellular $\mathrm{Ca}^{2+}$ mobilization by measuring $\left[{ }^{14} \mathrm{C}\right]-$ adenine release and chromium-51 release by drug-treated U937 cells. In these experiments, $\left[{ }^{14} \mathrm{C}\right]$ adenine- or chromium51-labeled U937 cells were incubated with test reagents as described in Methods. The experimental results are summarized in Table I. Our data indicate that none of the concentrations of test reagents used for the studies reported here showed any toxic effects on U937 cells as measured by either assay. We also examined the drug combinations used to generate the data pre-

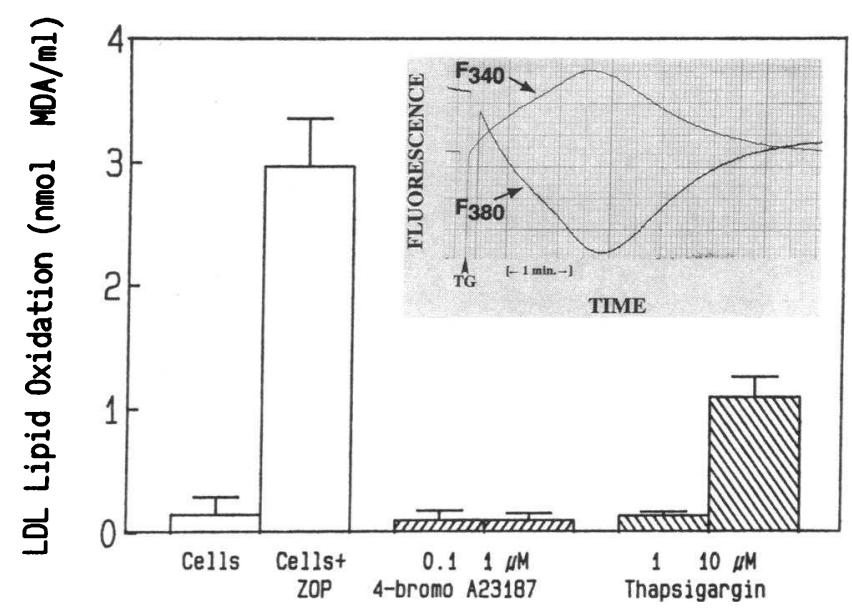

Figure 6. Effects of 4-bromo A23187 and thapsigargin on LDL lipid peroxidation by $\mathrm{U} 937$ cells. U937 cells $\left(5 \times 10^{5}\right.$ cells $\left./ \mathrm{ml}\right)$ were incubated with LDL in the presence (hatched bars) or absence (open bars) of 4-bromo A23187 or thapsigargin at $37^{\circ} \mathrm{C}$ for $24 \mathrm{~h}$ in a humidified incubator with $10 \% \mathrm{CO}_{2}$. Different concentrations of 4-bromo A23187 or thapsigargin were added to U937 cells as indicated: 4bromo A23187 0.1 or $1 \mu \mathrm{M}$, thapsigargin 1 or $10 \mu \mathrm{M}$. After the 24-h incubation, LDL lipid peroxidation was determined as described in Methods. The data are depicted as the mean \pm SEM of three similar experiments. LDL lipid peroxidation induced by ZOP was $2.97 \mathrm{nmol}$ $\mathrm{MDA} / \mathrm{ml}$. 4-bromo A23187 did not induce LDL lipid peroxidation by U937 cells. $10 \mu \mathrm{M}$ thapsigargin-induced LDL lipid peroxidation was $35 \%$ of that mediated by ZOP-activated U937 cells. (Inset) Intact U937 cells loaded with Fura 2 were challenged with $10 \mu \mathrm{M}$ thapsigargin. Fura 2 measurements were conducted as described in Methods. The $340 / 380 \mathrm{~nm}$ tracings are representative of at least three different experiments. 
Table I. Cytotoxic Effects of $\mathrm{Ca}^{2+}$ Channel Blockers and Inhibitors of Intracellular $\mathrm{Ca}^{2+}$ Mobilization on U937 Cells

\begin{tabular}{|c|c|c|c|c|}
\hline \multirow[b]{2}{*}{ Incubation additions* } & \multicolumn{2}{|c|}{ Adenine release } & \multicolumn{2}{|c|}{ Chromium release } \\
\hline & $10^{3} \mathrm{cpm}^{\ddagger}$ & $\begin{array}{l}\text { Percent } \\
\text { release }^{5}\end{array}$ & $10^{3} \mathrm{cpm}^{\ddagger}$ & $\begin{array}{l}\text { Percent } \\
\text { release }^{\S}\end{array}$ \\
\hline \multicolumn{5}{|l|}{ Unactivated cells } \\
\hline+ LDL & $11.66 \pm 0.33$ & - & $4.25 \pm 0.04$ & - \\
\hline \multicolumn{4}{|l|}{ Activated cells } & \\
\hline $\begin{array}{l}\text { DMSO (solvent } \\
\text { control) }\end{array}$ & $19.18 \pm 0.83$ & 0 & $3.95 \pm 0.10$ & 0 \\
\hline $\begin{array}{l}0.2 \% \text { SDS } \\
\quad \text { (total release) }\end{array}$ & $43.29 \pm 0.48$ & 100 & $24.42 \pm 1.00$ & 100 \\
\hline \multicolumn{5}{|l|}{ Nifedipine } \\
\hline $10 \mu \mathrm{M}$ & $16.05 \pm 0.37$ & 0 & $3.29 \pm 0.03$ & 0 \\
\hline $100 \mu \mathrm{M}$ & $17.97 \pm 1.13$ & 0 & $4.07 \pm 0.15$ & 0.6 \\
\hline \multicolumn{5}{|l|}{ Verapamil } \\
\hline $10 \mu \mathrm{M}$ & $18.83 \pm 0.33$ & 0 & $3.56 \pm 0.01$ & 0 \\
\hline $100 \mu \mathrm{M}$ & $19.52 \pm 0.11$ & 1.4 & $4.67 \pm 0.03$ & 3.5 \\
\hline \multicolumn{5}{|l|}{$\mathrm{La}^{3+}$} \\
\hline $10 \mu \mathrm{M}$ & $13.07 \pm 0.30$ & 0 & $2.88 \pm 0.07$ & 0 \\
\hline $100 \mu \mathrm{M}$ & $13.47 \pm 0.10$ & 0 & $3.52 \pm 0.08$ & 0 \\
\hline \multicolumn{5}{|l|}{ TMB-8 } \\
\hline $10 \mu \mathrm{M}$ & $16.88 \pm 0.34$ & 0 & ND & 0 \\
\hline $20 \mu \mathrm{M}$ & ND" & & $3.87 \pm 0.11$ & 0 \\
\hline $100 \mu \mathrm{M}$ & $16.58 \pm 0.44$ & 0 & $4.51 \pm 0.10$ & 2.7 \\
\hline \multicolumn{5}{|l|}{ Ryanodine } \\
\hline $0.1 \mu \mathrm{M}$ & $11.85 \pm 0.31$ & 0 & ND & \\
\hline $1 \mu \mathrm{M}$ & $15.19 \pm 0.41$ & 0 & $3.84 \pm 0.10$ & 0 \\
\hline $10 \mu \mathrm{M}$ & $16.04 \pm 0.23$ & 0 & $3.93 \pm 0.22$ & 0 \\
\hline
\end{tabular}

* U937 cells $\left(5 \times 10^{5} / \mathrm{ml}\right)$ were radiolabeled with $\left[{ }^{14} \mathrm{C}\right]$ adenine or chromium- 51 and then incubated together with LDL $(0.5 \mathrm{mg} / \mathrm{ml})$ and a variety of test agents as indicated in Methods. ${ }^{\ddagger}$ Release of radioactivity was determined as described in Methods. All experiments were performed in triplicate. The results are expressed as mean $\pm S D$ of data obtained in one of two similar experiments. ${ }^{\S}$ Percent release of $\left[{ }^{14} \mathrm{C}\right]$ adenine or chromium-51 was determined by the equation described in Methods. "ND, not done.

sented in Fig. 5 and found that none of these drug combinations was toxic for U937 cells (data not shown). Additionally, in a pilot study, we examined whether the effect of nifedipine could be reversed by removing it after pretreating U937 cells, to determine whether it irreversibly injured the cells. We found that after removing nifedipine ( $100 \mu \mathrm{M}) \mathrm{U} 937$ cells were capable of oxidizing LDL lipids to a similar degree as untreated cells; thus providing further support that an agent that inhibits calcium influx can profoundly inhibit LDL lipid peroxidation without injuring the monocytes.

Finally, we tested the antioxidant activity of the $\mathrm{Ca}^{2+}$ channel blockers and agents preventing $\mathrm{Ca}^{2+}$ release from intracellular stores that were used in the above studies to rule out a nonspecific inhibitory effect on U937 cells. The antioxidant activity was determined by measuring the effect of these test agents on copper-induced LDL lipid peroxidation. (Briefly, $\mathrm{CuSO}_{4}[5 \mu \mathrm{M}]$ and LDL [0.5 $\mathrm{mg}$ cholesterol $\left./ \mathrm{ml}\right]$ were incubated together in the presence or absence of test agents at $37^{\circ} \mathrm{C}$ for $24 \mathrm{~h}$. After incubation the degree of lipid peroxidation on LDL was determined by the TBA assay.) Nifedipine, verap- amil, lanthanum chloride, or TMB-8 had no antioxidant activity at the concentrations used in these experiments. Ryanodine at 0.1 and $1 \mu \mathrm{M}$ had no antioxidant activity whereas, at a concentration of $10 \mu \mathrm{M}$, it caused a $68 \%$ inhibition of copper-induced LDL lipid peroxidation (data not shown).

\section{Discussion}

The oxidation of LDL by monocytes requires monocyte activation by certain stimulating agents such as ZOP or bacterial LPS $(1,2)$. Zymosan is a particulate stimulus comprised of yeast cell walls and is opsonized with human serum before activating monocytes. Therefore, ZOP is coated with immunoglobulin and complement and likely interacts with monocytes through $\mathrm{Fc}$ and complement receptors as well as triggering phagocytosis. Our data show that the LDL lipid peroxidation by ZOP-activated U937 cells requires both the influx of extracellular $\mathrm{Ca}^{2+}$ and the release of sequestered intracellular $\mathrm{Ca}^{2+}$, since either blockade of $\mathrm{Ca}^{2+}$ influx by $\mathrm{Ca}^{2+}$ channel blockers or prevention of $\mathrm{Ca}^{2+}$ mobilization by TMB- 8 and ryanodine abolished the LDL lipid peroxidation. Thus, our findings indicate that $\mathrm{Ca}^{2+}$ functions as an important mediator in the process of LDL lipid peroxidation by ZOP-activated U937 cells.

Increases in intracellular $\mathrm{Ca}^{2+}$ can be achieved either by release of $\mathrm{Ca}^{2+}$ from internal stores or by influx of extracellular $\mathrm{Ca}^{2+}$ from medium. First, we examined the $\mathrm{Ca}^{2+}$ influx through $\mathrm{Ca}^{2+}$ channels in the cell plasma membrane. Both slow $\mathrm{Ca}^{2+}$ channel blockers nifedipine (dihydropyridine) and verapamil (phenylakylamine) have been shown to bind with $\mathrm{Ca}^{2+}$ channels on the plasma membrane in a variety of cells and tissues (21). The blockade of $\mathrm{Ca}^{2+}$ channels by nifedipine or verapamil affects a wide range of cell functions, such as reducing contraction of vascular smooth muscle and cardiac muscle (21), inhibiting proliferation and activation of T lymphocytes (17), and interfering with differentiation of U937 cells (22). Our data show that in the presence of nifedipine or verapamil the peroxidation of LDL lipids by activated monocytes is significantly decreased (Fig. 2 ) as is ${ }^{45} \mathrm{Ca}^{2+}$ influx (Fig. 4). Similarly, removal of extracellular $\mathrm{Ca}^{2+}$ by EGTA or by addition of lanthanum chloride, which competes with $\mathrm{Ca}^{2+}$ for $\mathrm{Ca}^{2+}$ channels (23) (or other $\mathrm{Ca}^{2+}$-binding sites), has the same inhibitory effect on LDL lipid peroxidation by activated U937 cells (Fig. 1). Our results thus indicate that blocking influx of extracellular $\mathrm{Ca}^{2+}$ inhibits LDL lipid peroxidation by activated U937 cells.

Our data also show differential effects of nifedipine and verapamil. Nifedipine caused $92 \%$ inhibition of monocyte-mediated LDL lipid peroxidation at a concentration of $100 \mu \mathrm{M}$ whereas verapamil showed only 55\% inhibition. Unfortunately, we were unable to measure intracellular $\mathrm{Ca}^{2+}$ concentrations using Fura 2 fluorescence because of the fact that ZOP is an extremely turbid particulate suspension. ${ }^{45} \mathrm{Ca}^{2+}$ uptake studies showed that there was an eightfold increase in intracellular calcium because of influx of $\mathrm{Ca}^{2+}$ upon monocyte activation by ZOP. Although both nifedipine and verapamil blocked the influx of extracellular $\mathrm{Ca}^{2+}$ at high concentrations, at lower concentrations only nifedipine blocked the influx of extracellular $\mathrm{Ca}^{2+}$ (see Fig. 4). These data suggest that U937 cells may contain multiregulated or multiple types of receptor-operated $\mathrm{Ca}^{2+}$ channels. Existence of multiple types of $\mathrm{Ca}^{2+}$ channels in the same tissue has been reported by Ratz and Flaim (24), who found that two types of receptor-operated $\mathrm{Ca}^{2+}$ channels ex- 
isted in smooth muscle of bovine coronary arteries, only one of which was sensitive to verapamil. Alternatively, nifedipine and verapamil may have differing binding sites and affinity for the same $\mathrm{Ca}^{2+}$ channel $(25,26)$, since their molecular structures are not the same. Furthermore, since U937 cells do not have the classic voltage-sensitive $L$ type channel, it is likely that nifedipine and verapamil operate differently in these cells than in smooth muscle cells. Precedence for the use of nifedipine and verapamil as inhibitors of $\mathrm{Ca}^{2+}$ influx has been established in U937 cells (22) and other nonexcitable cells such as T cells (17) and neutrophils (27). Finally, it was reported that in neutrophils (27) and skeletal muscle (28) nifedipine can also bind to intracellular plasma membrane such as sarcoplasmic reticulum (28) to prevent $\mathrm{Ca}^{2+}$ release. Thus, at high concentrations nifedipine may block both $\mathrm{Ca}^{2+}$ influx from extracellular medium and release from intracellular stores in U937 cells and thus prevent $\mathrm{Ca}^{2+}$-triggered intracellular signal transductions. Besides blockade of $\mathrm{Ca}^{2+}$ influx, it has been reported that nifedipine and verapamil have other potentially antiatheroslerotic effects, since both nifedipine and verapamil inhibit intracellular cholesteryl esterification in macrophages (29). The $\mathrm{Ca}^{2+}$ dependence of this latter observation remains to be determined.

We also examined the contribution of $\mathrm{Ca}^{2+}$ mobilization from internal stores to monocyte-mediated peroxidation of LDL lipids. Two agents reported to prevent $\mathrm{Ca}^{2+}$ release from internal membrane stores, TMB- 8 and ryanodine, were used. TMB-8 has been reported to prevent mobilization of $\mathrm{Ca}^{2+}$ from intracellular stores without altering $\mathrm{Ca}^{2+}$ influx into the cell $(18,30,31)$. Ryanodine is believed to bind to the $\mathrm{Ca}^{2+}$ release channel in the intracellular $\mathrm{Ca}^{2+}$ stores (32). Our data demonstrated that both TMB-8 and ryanodine had dose-dependent inhibitory effects on LDL lipid peroxidation by activated U937 cells (Fig. 3); an effect that was independent of direct antioxidant effects of these agents. Furthermore, neither agent inhibited ${ }^{45} \mathrm{Ca}^{2+}$ influx (Fig. 4). These results indicate that intracellular $\mathrm{Ca}^{2+}$ mobilization is required in the process of LDL lipid peroxidation.

Additionally, our data also show that $\mathrm{Ca}^{2+}$ channel blockers and agents known to prevent release of intracellular $\mathrm{Ca}^{2+}$ can have additive effects (Fig. 5). The inhibitory effects of these two types of reagents in combination were greater than either alone. These findings support the concept that increases in intracellular $\mathrm{Ca}^{2+}$ from intracellular and extracellular sources are not functionally equivalent. Similar observations have been made by Haverstick et al. (33) in T lymphocytes. Our findings indicate that intracellular $\mathrm{Ca}^{2+}$ concentrations regulated by both influx from the extracellular medium and release from intracellular stores are critical elements of the activation of monocytes/macrophages.

We also investigated whether direct stimulation of an increase in intracellular $\mathrm{Ca}^{2+}$ was sufficient to induce the peroxidation of LDL lipids observed with ZOP-activated U937 cells. U937 cells and LDL were incubated together with the $\mathrm{Ca}^{2+}$ ionophore 4-bromo A23187 or thapsigargin. This $\mathrm{Ca}^{2+}$ ionophore did not induce LDL lipid peroxidation with $5 \times 10^{5}$ U937 cells/ml (Fig. 6). Furthermore, the release of intracellular $\mathrm{Ca}^{2+}$ by thapsigargin only induced a suboptimal level of LDL lipid peroxidation (Fig. 6). This level of LDL lipid peroxidation was not enhanced by incubation with both thapsigargin and 4-bromo A23187 (data not shown). Therefore, the increases in intracellular $\mathrm{Ca}^{2+}$ levels are critical for optimal per- oxidation of LDL lipids by activated U937 cells to occur. Both influx and mobilization of $\mathrm{Ca}^{2+}$ are required but are not sufficient for stimulating LDL lipid peroxidation equivalent to that induced by ZOP.

The functional role of $\mathrm{Ca}^{2+}$ in the cellular response to exogenous stimulus likely involves the induction of several different intracellular signal transduction pathways. As is well recognized, monocytes and other phagocytes, if stimulated by ZOP, exhibit receptor-mediated induction of multiple intracellular signal transduction pathways $(7,34,35)$. The effect of ZOP has been suggested to induce the activation of phospholipase $\mathrm{C}$ (PLC), which catalyzes hydrolysis of phosphatidylinositides (34) and generates the intracellular second messengers inositol phosphates ( 35 ) and diacylglycerol. Inositol phosphates induce the mobilization of intracellular $\mathrm{Ca}^{2+}$ from internal stores. Thus, the increase in intracellular $\mathrm{Ca}^{2+}$ levels with ZOP could be mediated by inositol phosphates generated by activation of PLC. Recently, Van De Winkel et al. (36) showed that crosslinking of IgG Fc $\gamma$ receptor by monoclonal antibodies induced an increase in intracellular $\mathrm{Ca}^{2+}$ levels in U937 cells. Phospholipase $\mathrm{A}_{2}$ has been shown to be a $\mathrm{Ca}^{2+}$-dependent signaling mechanism as well (37). In other studies, we have found that inhibition, protein kinase $\mathrm{C}$, phospholipase $\mathrm{A}_{2}$, or lipoxygenase pathways by using selective inhibitors destroys the ability of ZOP-activated U937 cells to oxidize LDL (reference 3 and unpublished data).

Taken together, our results indicate that increases in intracellular $\mathrm{Ca}^{2+}$ are required for peroxidation of $\mathrm{LDL}$ lipids by activated monocytes. Although increased intracellular $\mathrm{Ca}^{2+} \mathrm{lev}$ els are necessary for LDL lipid peroxidation, several other intracellular signal transduction pathways are likely involved, since neither stimulation of $\mathrm{Ca}^{2+}$ influx from extracellular medium nor $\mathrm{Ca}^{2+}$ release from intracellular stores could individually or together induce LDL lipid peroxidation by monocytes equivalent to that induced by ZOP. ZOP must activate other signal transduction pathways that act in concert with increased intracellular $\mathrm{Ca}^{2+}$ to stimulate the peroxidation of LDL lipids by U937 cells.

\section{Acknowledgments}

The authors thank Drs. Meredith Bond and David Van Wagoner for their helpful discussions and the Cleveland Clinic Blood Bank for supplying human plasma.

This investigation was supported by grant 91012010 from the National American Heart Association.

Note added in proof. We have recently become aware of an article by Breugnot and colleagues reporting the inhibitory effect of calcium antagonists on monocyte-mediated oxidation of LDL. We regret that we did not include it in the body of our manuscript. The results of our studies with calcium antagonists reported here confirm and extend these findings. (Breugnot, C., C. Maziere, M. Auclair, L., Mora, M. F. Ronveaux, S. Salmon, R. Santus, P. Morliere, A. Lanaers and J. C. Maziere. 1991. Calcium antagonists prevent monocyte and endothelial cell-induced modification of low density lipoproteins. Free Radic. Res. Commun. 15:91-100.)

\section{References}

1. Cathcart, M. K., D. W. Morel, and G. M. Chisolm. 1985. Monocytes and neutrophils oxidize low density lipoprotein making it cytotoxic. J. Leukocyte Biol. 38:341-350.

2. Cathcart, M. K., A. K. McNally, D. W. Morel, and G. M. Chisolm. 1989. Superoxide anion participation in human monocyte-mediated oxidation of low- 
density lipoprotein and conversion of low-density lipoprotein to a cytotoxin. $J$. Immunol. 142:1963-1969.

3. Cathcart, M. K., A. K:McNally, and G. M. Chisolm. 1991. Lipoxygenasemediated transformation of human low density lipoprotein to an oxidized and cytotoxic complex. J. Lipid Res. 32:63-70.

4. Hessler, J. R., D. W. Morel, L. J. Lewis, and G. M. Chisolm. 1983. Lipoprotein oxidation and lipoprotein-induced cytotoxicity. Arteriosclerosis. 3:215-222.

5. Jurgens, G., H. F. Hoff, G. M. Chisolm, and H. Esterbauer. 1987. Modification of human serum low density lipoprotein by oxidation-characterization and pathophysiological implications. Chem. Phys. Lipids. 45:315-336.

6. Steinberg, D., S. Parthasarathy, T. E. Carew, J. C. Khoo, and J. L. Witztum. 1989. Beyond cholesterol. Modifications of low-density lipoprotein that increase its atherogenicity. N. Engl. J. Med. 320:915-924.

7. Czop, J. K., and K. F. Austen. 1980. Functional discrimination by human monocytes between their $\mathrm{C} 3 \mathrm{~b}$ receptors and their recognition units for particulate activators of the alternative complement pathway. J. Immunol. 125:124-128.

8. Schmitz, G., J. Hankowitz, and E. M. Kovacs. 1991. Cellular processes in atherogenesis: potential targets of $\mathrm{Ca}^{2+}$ channel blockers. Atherosclerosis. 88:109-132.

9. Cathcart, M. K., G. M. Chisolm, A. K. McNally, and D. W. Morel. 1988. Oxidative modification of low density lipoprotein (LDL) by activated human monocytes and the cell lines U937 and HL60. In Vitro Cell. Dev. Biol. 24:10011008.

10. Schuh, J., G. F. Fairclough, and R. H. Haschemeyer. 1978. Oxygen-mediated heterogeneity of apo-low-density lipoprotein. Proc. Natl. Acad. Sci. USA. 75:3173-3177.

11. El-Saadani, M., H. Esterbauer, M. El-Sayed, M. Goher, A. Y. Nassar, and G. Jurgens. 1989. A spectrophotometric assay for lipid peroxides in serum lipoproteins using a commercially available reagents. J. Lipid Res. 30:627-630.

12. Warren, J. B., and U. S. Ryan. 1989. Endothelial injury assessed by isotope release: ${ }^{3} \mathrm{H}$-adenine compared with ${ }^{51} \mathrm{Cr}$. In Vitro Cell. Dev. Biol. 25:334335.

13. Shirhatti, V., and G. Krishna. 1985. A simple and sensitive method for monitoring drug-induced cell injury in cultured cells. Anal. Biochem. 147:410 418.

14. Varani, J., S. H. Phan, D. F. Gibbs, U. S. Ryan, and P. A. Ward. 1990. $\mathrm{H}_{2} \mathrm{O}_{2}$-mediated cytotoxicity of rat pulmonary endothelial cells. Changes in adenosine triphosphate and purine products and effects of protective interventions. Lab. Invest. 63:683-689.

15. Grynkiewicz, G., M. Poenie, and R. Y. Tsien. 1985. A new generation of $\mathrm{Ca}^{2+}$ indicators with greatly improved fluorescence properties. J. Biol. Chem. 260:3440-3450.

16. Johnston, R. B. 1981. Secretion of superoxide anion. In Methods for Studying Mononuclear Phagocytes. D. O. Adams, P. J. Edelson, and H. Koren, editors. Academic Press, New York. 489-497.

17. Birx, D. L., M. Berger, and T. A. Fleisher. 1984. The interference of T cell activation by calcium channel blocking agents. J. Immunol. 133:2904-2909.

18. Donowitz, M., S. Cusolito, and G. W. G. Sharp. 1986. Effects of calcium antagonist TMB-8 on active $\mathrm{Na}$ and $\mathrm{Cl}$ transport in rabbit ileum. Am. J. Physiol. 250:G691-G697.

19. Zimanyi, I., and I. N. Pessah. 1991. Comparison of $\left[{ }^{3} \mathrm{H}\right]$ ryanodine receptors and $\mathrm{Ca}^{2+}$ release from rat cardiac and rabbit skeletal muscle sarcoplasmic reticulum. J. Pharmacol. Exp. Ther. 256:938-946.

20. Thastrup, O., P. J. Cullen, B. K. Drobak, M. R. Hanley, and A. P. Dawson. 1990. Thapsigargin, a tumor promter, discharges intracellular $\mathrm{Ca}^{2+}$ stores by specific inhibition of the endoplasmic reticulum $\mathrm{Ca}^{2+}$-ATPase. Proc. Natl. Acad. Sci. USA. 87:2466-2470.

21. Hosey, M. M., and M. Lazdunski. 1988. Calcium channels: molecular pharmacology, structure and regulation. J. Membr. Biol. 104:81-105.

22. Pedrinaci, S., F. Ruiz-Cabello, O. Gomez, A. Collado, and F. Garrido. 1990. Protein kinase C-mediated regulation of the expression of CD14 and CD11/CD18 in U937 cells. Int. J. Cancer. 45:294-298.

23. Gould, R. J., K. M. M. Murphy, and S. H. Snyder. 1982. [ ${ }^{3}$ H]Nitrendipine-labeled calcium channels discriminate inorganic calcium agonists and antagonists. Proc. Natl. Acad. Sci. USA. 79:3656-3660.

24. Ratz, P. H., and S. F. Flaim. 1985. Acetylcholine- and 5-hydroxytryptamine-stimulated contraction and calcium uptake in bovine coronary arteries: evidence for two populations of receptor-operated calcium channels. J. Pharmacol. Exp. Ther. 234:641-647.

25. Catterall, W. A. 1988. Structure and function of voltage-sensitive ion channels. Science (Wash. DC). 242:50-61.

26. Zobrist, R. H., K. M. Giacomini, W. L. Nelson, and J. C. Giacomini. 1986. The interaction of phenylalkylamine calcium channel blockers with 1.4-dihydropyridine binding site. J. Mol. Cell. Cardiol. 18:963-974.

27. Rosales, C., and E. J. Brown. 1992. Calcium channel blockers nifedipine and diltiazem inhibit $\mathrm{Ca}^{2+}$ release from intracellular stores in neutrophils. J. Biol. Chem. 267:1443-1448.

28. Rios, E., and G. Brum. 1987. Involvement of dihydropyridine receptors in excitation-contraction coupling in skeletal muscle. Nature (Lond.). 325:717720.

29. Daugherty, A., D. L. Rateri, G. Schonfeld, and B. E. Sobel. 1987. Inhibition of cholesteryl ester deposition in macrophages by calcium entry blockers: an effect dissociable from calcium entry blockade. Br. J. Pharmacol. 91:113-118.

30. Chiou, C. Y., and M. H. Malagodi. 1975. Studies on the mechanism of action of a new $\mathrm{Ca}^{2+}$ antagonist, 8-( $N, N$-diethylamino) octyl 3,4,5-trimethoxybenzoate hydrochloride in smooth and skeletal muscles. Br. J. Pharmacol. 53:279-285.

31. Mix, L. L., R. J. Dinerstein, and M. L. Villereal. 1984. Mitogens and melittin stimulate an increase in intracellular free calcium concentration in human fibroblasts. Biochem. Biophys. Res. Commun. 119:69-75.

32. Fill, M., and R. Coronado. 1988. Ryanodine receptor channel of sarcoplasmic reticulum. Trends Neurosci. 11:453-457.

33. Haverstick, D. M., V. H. Engelhard, and L. S. Gray. 1991. Three intracellular signals for cytotoxic $\mathrm{T}$ lymphocyte-mediated killing. Independent roles for protein kinase $\mathrm{C}, \mathrm{Ca}^{2+}$ influx, and $\mathrm{Ca}^{2+}$ release from internal stores. J. Immunol. 146:3306-3313.

34. Leslie, C. C., and D. M. Detty. 1986. Arachidonic acid turnover in response to lipopolysaccharide and opsonized zymosan in human monocyte-derived macrophages. Biochem. J. 236:251-259.

35. Hoffman, T., C. Brando, E. F. Lizzio, Y. L. Lee, M. Hansen, A. K. Tripathi, M. Taplits, J. Puri, E. Bonvini, T. G. Abrahamsen, et al. 1991. Calciumdependent eicosanoid metabolism by concanavalin A-stimulated human monocytes in vitro. Synergism with phorbol ester indicates separate regulation of leukotriene $B_{4}$ synthesis and release. J. Immunol. 146:692-700.

36. Van De Winkel, J. G. J., W. J. M. Tax, C. W. M. Jacobs, T. W. J. Huizinga, and P. H. G. M. Willems. 1990. Cross-linking of both types of IgG Fc receptor, Fc $\gamma \mathrm{RI}$ and $\mathrm{Fc} \gamma \mathrm{RII}$, enhances intracellular free $\mathrm{Ca}^{2+}$ in the monocytic cell line U937. Scand. J. Immunol. 31:315-325.

37. Chang, J., J. H. Musser, and H. McGregor. 1987. Phospholipase $\mathrm{A}_{2}$ : function and pharmacological regulation. Biochem. Pharmacol. 36:2429-2436. 